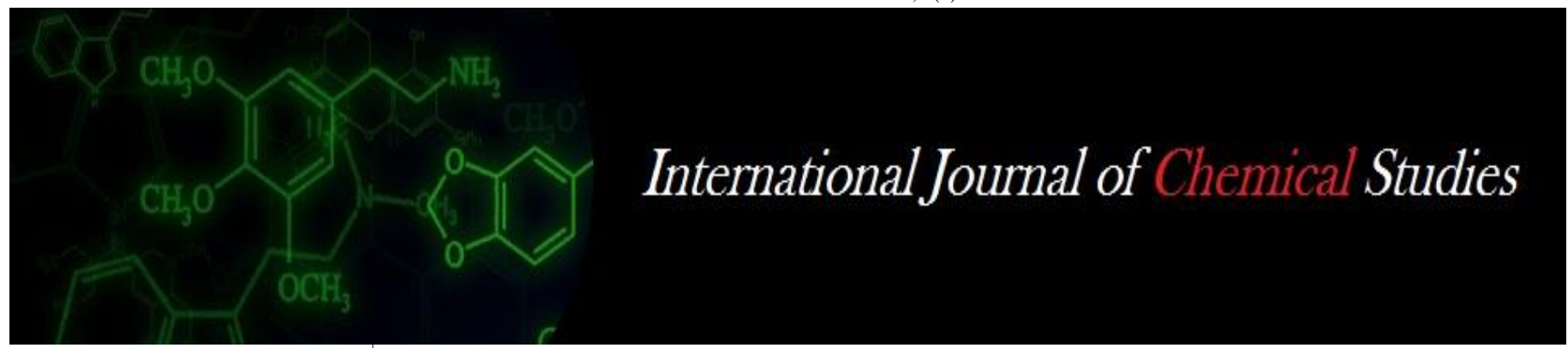

P-ISSN: 2349-8528

E-ISSN: 2321-4902

www.chemijournal.com

IJCS 2020; 8(4): 1669-1672

(C) 2020 IJCS

Received: 04-05-2020

Accepted: 06-06-2020

\section{B Rajyalakshmi}

Department of Agronomy and

Agricultural College, ANGRAU,

Bapatla, Andhra Pradesh, India

\section{B Venkateswarlu}

Department of Agronomy and Agricultural College, ANGRAU,

Bapatla, Andhra Pradesh, India

\section{PVN Prasad}

Department of Agronomy and Agricultural College, ANGRAU, Bapatla, Andhra Pradesh, India

\section{PRK Prasad}

Department of Soil Science and Agricultural Chemistry,

Agricultural College, ANGRAU,

Bapatla, Andhra Pradesh, India

Corresponding Author:

B Rajyalakshmi

Department of Agronomy and

Agricultural College, ANGRAU,

Bapatla, Andhra Pradesh, India

\section{Nutrient uptake studies of mustard as influenced by seed rates and varieties in rice fallows}

\author{
B Rajyalakshmi, B Venkateswarlu, PVN Prasad and PRK Prasad
}

DOI: https://doi.org/10.22271/chemi.2020.v8.i4q.9850

\begin{abstract}
Field experiment was conducted on clay soils during rabi, 2017-2018 of Agricultural College Farm, Bapatla to study the influence of seed rates and varieties on nutrients (N, P and K) uptake of rice fallow mustard. The treatments consisted of four seed rates and three varieties and replicated thrice with factorial randomized block design. As regards, results revealed that significantly highest plant height $(113.0 \mathrm{~cm})$, drymatter accumulation $\left(2059 \mathrm{~kg} \mathrm{ha}^{-1}\right)$, seed yield $\left(650 \mathrm{~kg} \mathrm{ha}^{-1}\right)$ and $\mathrm{N}, \mathrm{P}$ and $\mathrm{K}$ uptake were recorded in seed rate $12 \mathrm{~kg} \mathrm{ha}^{-1}$ at all the growth stages. Among varieties PM-28 significantly recorded highest plant height $(110.1 \mathrm{~cm})$, drymatter accumulation $\left(1992 \mathrm{~kg} \mathrm{ha}^{-1}\right)$, seed yield $\left(665 \mathrm{~kg} \mathrm{ha}^{-1}\right)$ and $\mathrm{N}, \mathrm{P}$ and $\mathrm{K}$ uptake at all the growth stages. The interaction between seed rates and varieties was found not significant for drymatter, seed yield, straw yield and NPK uptake of rice fallow mustard.
\end{abstract}

Keywords: Mustard, seed rates, varieties, seed yield and nutrient uptake

\section{Introduction}

Globally, India is the third largest producer of mustard (Brassica juncea L.) after soybean and oil palm (Piri et al., 2011) ${ }^{[15]}$ having 5.9 million hectares acreage with 6.4 million tonnes production but average yield is only $1145 \mathrm{~kg} \mathrm{ha}^{-1}$ (Economic survey, 2013) ${ }^{[3]}$. Among the seven edible oilseeds cultivated in India, rapeseed-mustard contributes $28.6 \%$ in the total production of oilseeds. However, in Andhra Pradesh, the area and production of mustard is 0.6 lakh hectares and 0.3 lakh tonnes respectively with productivity of $500 \mathrm{~kg} \mathrm{ha}^{-1}$ in $2014-15$ (http://www.indiastat.com) ${ }^{[9]}$. Indian mustard is the major source of quality edible oil and for increasing the productivity of mustard crop the improved varieties which have potential for giving higher yields like hybrids need to be cultivated by farmers. The crop can be raised well both under irrigated and rainfed conditions, and also on residual fertility and residual soil moisture conditions, in rice fallows. Effective management of natural resources, integrated approach to plant water, nutrient and pest management and extension of mustard cultivation to newer areas under different cropping systems will play a key role in further increasing and stabilizing the productivity and production of mustard. Important physiological attributes such as planting dates, row to row spacing, plant density, sowing methods, seed rate, plant height, number of leaves per plant, number of filled siliqua per plant, number of seed per siliqua, 1000 seed weight and yield etc can address various constraints of a variety for increasing its productivity (Mondal et al., 1999) ${ }^{[10]}$. There is a vast scope for increasing the yield of mustard by cultivating improved varieties and following best bet practices. (Panda et al., 2004) ${ }^{[13]}$ has also reported that the yield potential of different mustard varieties may differ under different agro-climatic conditions because of their inherent capacity. The mustard genotypes differ in their yielding ability, this call for a need to generate more information on the response of mustard genotypes for greater yields in rice-fallow conditions. Suitable seed rate and improved varieties are extreme important practices for mustard production in order to achieve higher yields. However, the information on nutrient uptake studies of mustard with respect to seed rate and varieties are still lacking in India. Therefore, the present study was undertaken to find out the effect of seed rates and varieties on nutrients (N, P and $\mathrm{K}$ ) uptake of rice fallow mustard. 


\section{Materials and Methods}

A field experiment was carried out on clay soil of Agricultural College Farm, Bapatla during rabi, 2017-18. The soil was saline in reaction and low in organic carbon $(0.02 \%)$, low in available nitrogen (226.77 $\left.\mathrm{kg} \mathrm{ha}^{-1}\right)$, medium in available phosphorus (31.95 kg ha-1) and high in available potassium $\left(556.45 \mathrm{~kg} \mathrm{ha}^{-1}\right)$. The experiment was laid out in factorial randomized block design with three replications. The treatment comprised of four seed rates $\left(\mathrm{S}_{1}: 6 \mathrm{~kg} \mathrm{ha}^{-1}, \mathrm{~S}_{2}: 8 \mathrm{~kg}\right.$ $\mathrm{ha}^{-1}, \mathrm{~S}_{3}: 10 \mathrm{~kg} \mathrm{ha}^{-1}, \mathrm{~S}_{4}: 12 \mathrm{~kg} \mathrm{ha}^{-1}$ ) allotted to factor-A and three varieties $\left(\mathrm{V}_{1}: \mathrm{NPJ}-112, \mathrm{~V}_{2}:\right.$ PM-28, $\mathrm{V}_{3}$ : Pusa bold) allotted to factor-B. Mustard was sown on $1^{\text {st }}$ December 2017. Mustard was grown on residual soil fertility and broadcasted before four days of harvesting of rice. The experiment was sown on 01-12-2018 and harvested on 23-02-2018. During the crop growth season climate was nearer to normal. The weekly mean maximum temperatures ranged from $29.94{ }^{\circ} \mathrm{C}$ to $35.02{ }^{\circ} \mathrm{C}$ and the weekly mean minimum temperatures ranged from $16.01{ }^{0} \mathrm{C}$ to $19.31{ }^{0} \mathrm{C}$ with average maximum temperature of $30.89{ }^{\circ} \mathrm{C}$ and minimum temperature of 17.82 ${ }^{0} \mathrm{C}$. The weekly mean relative humidity ranged from 60.80 to 74.65 per cent with an average of 71.33 per cent. No rainfall was received during the entire crop growth period. Overall, the climatic conditions were normal and suitable for the successful cultivation of mustard crop with little incidence of pests which were controlled by suitable insecticidal sprays and there was no disease incidence. The crop was grown on residual soil moisture and irrigation was not given to the crop.

\section{Results}

Data pertaining to growth characters of rice fallow mustard (Table 1) reveals that plant height at 30 days after sowing (DAS) was not significantly influenced by seed rates, varieties and also by their interaction. At 60 DAS and harvest, $12 \mathrm{~kg} \mathrm{ha}^{-1}$ seed rate significantly influenced the plant height with tallest plants 110.3 and $113.0 \mathrm{~cm}$ respectively, and the lowest plant height was obtained with the seed rate $6 \mathrm{~kg} \mathrm{ha}^{-1}$. Among varieties, PM-28 recorded significantly taller plants with 107.9 and $110.1 \mathrm{~cm}$ at 60 DAS and harvest respectively which was statistically comparable with NPJ-112. The lowest plant height was recorded with the variety Pusa bold. The seed rate $12 \mathrm{~kg} \mathrm{ha}^{-1}$ registered significantly highest drymatter accumulation 262, 1628 and $2059 \mathrm{~kg} \mathrm{ha}^{-1}$ at 30,60 DAS and harvest respectively and closely followed by $10 \mathrm{~kg}$ seed rate $\mathrm{ha}^{-1}$ and lowest in $6 \mathrm{~kg}$ seed rate $\mathrm{ha}^{-1}$ this is mainly due to the availability of natural resources for proper growth and development. Pertaining to varieties, PM-28 variety recorded significantly the highest drymatter with 253, 1576 and 1992 $\mathrm{kg} \mathrm{ha}^{-1}$ at 30, 60 DAS and harvest respectively, and was statistically on par with the variety NPJ-112 and significantly superior over Pusa bold. The seed and stalk yields of rice fallow mustard (Table 1) varied significantly due to different seed rates. The highest seed $\left(650 \mathrm{~kg} \mathrm{ha}^{-1}\right)$ and stalk $(1450 \mathrm{~kg}$ $\mathrm{ha}^{-1}$ ) yields were recorded with $12 \mathrm{~kg}$ seed rate ha- ${ }^{-1}$ and lowest seed and stalk yields in $6 \mathrm{~kg}$ seed rate $\mathrm{ha}^{-1}$. Seed yield of rice fallow mustard was also significantly influenced by the varieties under test. The highest seed $\left(665 \mathrm{~kg} \mathrm{ha}^{-1}\right)$ and stalk yields (1652 $\mathrm{kg} \mathrm{ha}^{-1}$ ) were registered by PM-28 variety which was significantly superior to seed $\left(511 \mathrm{~kg} \mathrm{ha}^{-1}\right)$ and stalk yields $\left(1179 \mathrm{~kg} \mathrm{ha}^{-1}\right)$ of Pusa bold variety.

It is evident from Table 2 that nitrogen uptake at $12 \mathrm{~kg}$ seed rate $\mathrm{ha}^{-1}$ registered significantly highest nitrogen uptake at 30 DAS (1.43 kg ha-1), 60 DAS $\left(14.28 \mathrm{~kg} \mathrm{ha}^{-1}\right)$, seed $(27.13 \mathrm{~kg}$ $\left.\mathrm{ha}^{-1}\right)$ and stalk $\left(23.63 \mathrm{~kg} \mathrm{ha}^{-1}\right)$ which was superior over $8 \mathrm{~kg}$ seed rate $\mathrm{ha}^{-1}$ and $6 \mathrm{~kg}$ seed rate $\mathrm{ha}^{-1}$. At the same time, variety PM-28 recorded significantly the highest nitrogen uptake at 30DAS (1.36 kg ha-1), 60 DAS $\left(14.31 \mathrm{~kg} \mathrm{ha}^{-1}\right)$, seed (27.61 $\left.\mathrm{kg} \mathrm{ha}^{-1}\right)$ and stalk (26.56 kg ha-1) and lowest with variety Pusa bold at all growth stages. Similarly, the highest phosphorus uptake at 30 DAS $\left(1.25 \mathrm{~kg} \mathrm{ha}^{-1}\right), 60$ DAS $(8.10 \mathrm{~kg}$ $\mathrm{ha}^{-1}$ ), seed (14.86 kg ha-1) and stalk (13.04 $\left.\mathrm{kg} \mathrm{ha}^{-1}\right)$ were observed in $12 \mathrm{~kg}$ seed rate $\mathrm{ha}^{-1}$. Among varieties PM-28 recorded significantly the highest phosphorus uptake at 30 DAS (1.21 kg ha-1), 60 DAS $\left(7.81 \mathrm{~kg} \mathrm{ha}^{-1}\right)$, seed $(14.80 \mathrm{~kg} \mathrm{ha}$ $\left.{ }^{1}\right)$ and stalk $\left(14.61 \mathrm{~kg} \mathrm{ha}^{-1}\right)$. The lowest phosphorus uptake was registered with variety Pusa bold at all the phenophases. Data on potassium uptake indicates that the seed rate $12 \mathrm{~kg} \mathrm{ha}^{-1}$ registered significantly the highest potassium uptake at 30 DAS $\left(2.87 \mathrm{~kg} \mathrm{ha}^{-1}\right), 60$ DAS $\left(18.76 \mathrm{~kg} \mathrm{ha}^{-1}\right)$, seed $(22.92 \mathrm{~kg}$ $\mathrm{ha}^{-1}$ ) and stalk (44.27 $\mathrm{kg} \mathrm{ha}^{-1}$ ) which was significantly superior over $8 \mathrm{~kg}$ seed rate $\mathrm{ha}^{-1}$ and $6 \mathrm{~kg}$ seed rate ha- ${ }^{-1}$. Amongst varieties, PM-28 recorded significantly the highest potassium uptake at 30 DAS $\left(2.73 \mathrm{~kg} \mathrm{ha}^{-1}\right), 60$ DAS $(17.80 \mathrm{~kg}$ $\mathrm{ha}^{-1}$ ), seed (23.34 $\mathrm{kg} \mathrm{ha}^{-1}$ ) and stalk (47.72 $\left.\mathrm{kg} \mathrm{ha}^{-1}\right)$. The lowest potassium uptake was registered with variety Pusa bold at all the stages of crop growth.

\section{Discussion}

Plant height increased with increase in age of the crop. Rate of plant growth is low in young stage and increased with age. Taller plants in the plots with high population levels might be due to overcrowded plant densities and the inter plant competition that could result in more cell division, cell elongation in search of light and other natural resources. For the rapid division and elongation of this apical meristem, where light plays major role increased plant height in search of sunlight (Keivanrad and Zandi, 2014) ${ }^{[6]}$. At low plant densities, lower interplant competition and sufficiency of light availability might have not encouraged the plants to grow taller. Greater light interception, efficient utilization of soil moisture and nutrients under low degree of inter-plant competition at wider spacing might have resulted in dwarfer plants when compared to plants at high population levels. Similar findings were reported by Fathy and Ahmed (2009) ${ }^{[5]}$, Rashid et al., (2010) [16], Naseri et al., (2012) ${ }^{[11]}$ and Patel et al., (2017) ${ }^{[14]}$. At optimum seed rate better availability of nutrients and other resources promoted the maximum drymatter accumulation leading to higher grain yield due to balanced source and sink relationship. The tallest and thickest plants, and as well the highest area of photosynthetic leaves and in turn increased the capacity of drymatter accumulation in the different plant parts. The current findings are in conformity with the findings of Al-Doori (2012) ${ }^{[1]}$. Among varieties of mustard genotypic growth potential of different varieties might have caused the variation in drymatter accumulation and higher in variety PM-28 as reported by Shanker et al., (2011) ${ }^{[18]}$ and Singh et al., (2017) ${ }^{[20]}$.

The higher seed yield with $12 \mathrm{~kg}$ seed rate ha-1 probably due to higher dry matter partitioning, elevated yield attributes, higher nutrient uptake towards economic part and better light interception (Khajuria et al., 2017) [7]. Higher plant population at higher seed rates, taller plants and more drymatter per unit area at higher plant populations might be the reason for the higher stalk yield at higher populations. Similar findings were also reported by Thakuria and Thakuria (2014) ${ }^{[22]}$. Production of higher yield by different varieties might be due to the contribution of cummulative favorable effects of the crop characteristics. Variety PM-28 resulted higher stalk yield may be due to the plant height, drymatter accumulation and number of branches per plant were higher 
in PM-28 variety, such varietal variation was also ascribed by other scientists such as Meena et al., (2013) ${ }^{[8]}$.

Significantly higher uptake of nitrogen, phosphorous and potassium could be attributed due to higher plant density contributed higher plant dry matter and production which led to higher nutrient uptake by plants (Khajuria et al., 2017) ${ }^{[7]}$. Nutrients uptake was significantly influenced due to the fact that the drymatter was multiplied with the nitrogen content. Similar results were also reported by earlier scientists Evaraarts and Beusichen (1998) ${ }^{[4]}$ and Daulagupu and
Thakuria (2016) ${ }^{[2]}$. The current results are in conformity with the findings of Singh et al., (2010) ${ }^{[21]}$ and Saud and Singh (2011) ${ }^{[17]}$. With respect to varieties, PM-28 resulted higher nitrogen, phosphorus and potassium uptake might be due to the fact that the drymatter accumulation was multiplied with the nitrogen content and there was a significant difference in nutrient uptake as influenced by varieties. Higher drymatter accumulation per unit area might be the reason for higher nitrogen uptake. Pachauri et al., (2012) ${ }^{[12]}$ and Sharma (2013) ${ }^{[19]}$ also confirm the current findings.

Table 1: Plant height, drymatter accumulation, seed yield and stalk yield of rice fallow mustard as influenced by seed rates and varieties

\begin{tabular}{|c|c|c|c|c|c|c|c|c|}
\hline \multirow{2}{*}{ Treatment } & \multicolumn{3}{|c|}{ Plant height (cm) } & \multicolumn{5}{|c|}{ Drymatter accumulation $\left(\mathrm{kg} \mathrm{ha}^{-1}\right)$ Seed yield Stalk yield } \\
\hline & \multicolumn{3}{|c|}{\begin{tabular}{|l|l|l|l|}
30 & DAS 60 & DASAt harvest \\
\end{tabular}} & t 30 DAS & 60 DAS & At harvest & $\left(\mathrm{kg} \mathrm{ha}^{-1}\right)$ & $\left(\mathrm{kg} \mathrm{ha}^{-1}\right)$ \\
\hline \multicolumn{9}{|c|}{ Seed rates $\left(\mathrm{kg} \mathrm{ha}^{-1}\right)$} \\
\hline$S_{1}-6$ & 15.9 & 99.2 & 101.2 & 198 & 1232 & 1558 & 565 & 1300 \\
\hline $\mathrm{S}_{2}-8$ & 16.3 & 101.2 & 103.2 & 225 & 1400 & 1770 & 577 & 1346 \\
\hline $\mathrm{S}_{3}-10$ & 16.6 & 107.2 & 109.4 & 233 & 1451 & 1835 & 601 & 1395 \\
\hline $\mathrm{S}_{4}-12$ & 17.1 & 110.3 & 113.0 & 262 & 1628 & 2059 & 650 & 1450 \\
\hline \begin{tabular}{|l|} 
S.Em \pm \\
\end{tabular} & 0.6 & 2.6 & 2.7 & 12.5 & 77.4 & 97.9 & 20.9 & 36.3 \\
\hline $\mathrm{CD}(\mathrm{p}=0.05)$ & NS & 7.5 & 7.8 & 36 & 227 & 287 & 59 & 106 \\
\hline \multicolumn{9}{|c|}{ Varieties } \\
\hline NPJ-112 & 16.1 & 105.7 & 108.2 & 224 & 1393 & 1761 & 618 & 1287 \\
\hline PM-28 & 17.1 & 107.9 & 110.1 & 253 & 1576 & 1992 & 665 & 1652 \\
\hline Pusa bold & 16.3 & 99.8 & 101.9 & 211 & 1316 & 1663 & 511 & 1179 \\
\hline S.Em \pm & 0.5 & 2.2 & 2.3 & 10.8 & 67.1 & 84.8 & 17.5 & 31.4 \\
\hline $\mathrm{CD}(\mathrm{p}=0.05)$ & NS & 6.5 & 6.8 & 31 & 196 & 248 & 51 & 92 \\
\hline \multicolumn{9}{|c|}{ Interaction (S X V) } \\
\hline \begin{tabular}{|l|} 
S.Em \pm \\
\end{tabular} & 1.1 & 4.5 & 4.6 & 21.6 & 134.1 & 169.6 & 34.9 & 62.9 \\
\hline $\mathrm{CD}(\mathrm{p}=0.05)$ & NS & NS & $\mathrm{NS}$ & $\mathrm{NS}$ & NS & NS & $\mathrm{NS}$ & $\mathrm{NS}$ \\
\hline \begin{tabular}{|l|}
$\mathrm{CV}(\%)$ \\
\end{tabular} & 11.1 & 7.3 & 7.5 & 14.6 & 16.2 & 15.7 & 10.1 & 7.4 \\
\hline
\end{tabular}

NS: Non significant

Table 2: Nitrogen, Phosphorus and Potassium uptake of rice fallow mustard at different growth stages as influenced by seed rates and varieties

\begin{tabular}{|c|c|c|c|c|c|c|c|c|c|c|c|c|}
\hline \multirow{3}{*}{ Treatment } & \multicolumn{4}{|c|}{ Nitrogen uptake $\left(\mathrm{kg} \mathrm{ha}^{-1}\right)$} & \multicolumn{4}{|c|}{ Phosphorus uptake $\left(\mathrm{kg} \mathrm{ha}^{-1}\right)$} & \multicolumn{4}{|c|}{ Potassium uptake $\left(\mathrm{kg} \mathrm{ha}^{-1}\right)$} \\
\hline & \multirow{2}{*}{$\begin{array}{c}\text { 30 } \\
\text { DAS }\end{array}$} & \multirow{2}{*}{$\begin{array}{c}60 \\
\text { DAS } \\
\end{array}$} & \multicolumn{2}{|c|}{ At harvest } & \multirow{2}{*}{$\begin{array}{c}\text { 30 } \\
\text { DAS }\end{array}$} & \multirow{2}{*}{$\begin{array}{c}60 \\
\text { DAS } \\
\end{array}$} & \multicolumn{2}{|c|}{ At harvest } & \multirow{2}{*}{$\begin{array}{c}30 \\
\text { DAS }\end{array}$} & \multirow{2}{*}{$\begin{array}{c}\text { 60 } \\
\text { DAS }\end{array}$} & \multicolumn{2}{|c|}{ At harvest } \\
\hline & & & Seed & Stalk & & & Seed & Stalk & & & Seed & Stalk \\
\hline \multicolumn{13}{|c|}{ Seed rates $\left(\mathrm{kg} \mathrm{ha}^{-1}\right)$} \\
\hline$S_{1}-6$ & .13 & 11.16 & 21.10 & 17.94 & 0.99 & 6.43 & 10.80 & 9.87 & 2.15 & 14.07 & 17.82 & 35.52 \\
\hline & 15 & & & 19.21 & 1.02 & & & & 20 & 4.36 & & 7.80 \\
\hline $\mathrm{S}_{3}-10$ & 1.2 & & & 22.12 & 1.08 & 7.01 & & 12.17 & 2.33 & 15.21 & & 41.66 \\
\hline & 1.43 & 14.28 & 27.13 & 23.63 & 1.2 & 8.11 & 14.8 & 13.04 & 2.87 & 18.76 & 92 & 44.27 \\
\hline S.Em \pm & 0.07 & 0.79 & & 1.48 & 0.0 & & & & & 1.01 & & \\
\hline $\mathrm{CD}($ & 0.22 & & & 4.36 & 0.19 & 1.26 & & & & 2.97 & & 5.31 \\
\hline \multicolumn{13}{|c|}{ Varieties } \\
\hline & 1.26 & 12.58 & 24.43 & 17.85 & 1.06 & 6.84 & 13.19 & 9.82 & 2.42 & 15.77 & 20.64 & 35.30 \\
\hline & 1.36 & 14.31 & 27. & 26.56 & 1.21 & 7.8 & 14.80 & 14.61 & 2.73 & 17.80 & 23.34 & 47.72 \\
\hline & 1.10 & 11.52 & 19. & 17.76 & 1.0 & & & & 2.03 & 13.25 & 16.18 & 33.92 \\
\hline & 0 & & & 1.28 & & & & & & 0.88 & .09 & 1.57 \\
\hline $\mathrm{CD}(\mathrm{p}=0.05)$ & 0.19 & 2.00 & 3.78 & 3.77 & 0.17 & 1.09 & 1.74 & 1.92 & 0.39 & 2.58 & 3.20 & 4.60 \\
\hline \multicolumn{13}{|c|}{ Interaction (S X V) } \\
\hline S.Em \pm & 0.13 & 1.36 & 2.58 & 2.57 & 0.11 & 0.74 & 1.19 & 1.31 & 0.27 & 1.79 & 2.18 & 3.14 \\
\hline $\mathrm{CD}(\mathrm{p}=0.0$ & NS & $\mathrm{NS}$ & NS & NS & $\mathrm{NS}$ & NS & NS & NS & NS & NS & $\mathrm{NS}$ & NS \\
\hline $\mathrm{CV}(\%)$ & 18.85 & 18.50 & 18.58 & 21.51 & 18.40 & 18.40 & 16.38 & 19.97 & 19.52 & 18.39 & 18.85 & 13.6 \\
\hline
\end{tabular}

\section{Conclusion}

The present study indicated that $12 \mathrm{~kg} \mathrm{ha}^{-1}$ seed rate registered higher plant height, drymatter, seed and stalk yields, NPK uptake and hence $12 \mathrm{~kg}$ seed rate $\mathrm{ha}^{-1}$ was found to be optimum in rice-fallows compared to $10 \mathrm{~kg} \mathrm{ha}^{-1}, 8 \mathrm{~kg} \mathrm{ha}^{-1}$ and $6 \mathrm{~kg} \mathrm{ha}{ }^{-1}$ seed rates. Among varieties PM-28 variety performed better than NPJ-112 and Pusa bold with higher plant height, drymatter accumulation, seed and stalk yields and NPK uptake.

\section{References}

1. Al-Doori SAM. Response of yield, yield components and seed quality of some rapeseed genotypes (Brassica napus L.) to plant density under rainfed conditions. College of Basic Education Researchers Journal. 2012; 12(4):957968.

2. Daulagupu K, Thakuria K. Effect of planting geometry and fertilizer levels on Yellow Sarson (Brassica rapa var. trilocularis) under rainfed condition. Journal of Oilseed Brassica. 2016; 7(2):169-173. 
3. Economic survey. Statistical appendix. Ministry of Home affairs. Government of India. 2013; A17-A19. [Available online: http://indianbudget.nic.in].

4. Everaarts AP, Beusichem MV. The effect of planting date and plant density on potassium and magnesium uptake and harvest by Brussels sprouts. Journal of Agronomy and Crop science. 1998; 181(4):201-207.

5. Fathy El-Nakhlawy S, Ahmed AB. Performance of canola (Brassica napas L.) seed yield, yield components and seed quality under the effects of four genotypes and nitrogen fertilizer rates. Meteorology, Environment and Arid Land Agriculture Sciences. 2009; 20(2):33-47.

6. Keivanrad S, Zandi P. Effect of nitrogen levels on growth, yield and oil quality of Indian mustard grown under different plant densities. Cercetari Agronomice in Moldova. 2014; 47(1):81-95.

7. Khajuria S, Dwivedi MC, Kumar S, Dileep K, Puniya R. Yield performance and nutrient uptake of Indian Mustard (Brassica juncea L.) varieties under different dates of sowing and planting geometry. International Journal of Plant \& Soil Science. 2017; 15(1):1-6.

8. Meena DS, Meena VR, Meena AK. Fertilizer management studies on growth and productivity of hybrid Indian mustard Brassica juncea (L.). Journal of Oilseed Brassica. 2013; 1(1):39-42.

9. Ministry of Agriculture, Government of India, (2014-15). [Available online: http://www.indiastat.com].

10. Mondal RI, Biswas M, Hydar-Ali MK, Akbar MA. Response of rapeseed genotypes Dhali to seed rate and seeding date. Bangladesh Journal of Agriculture Research. 1999; 24(1):83-90.

11. Naseri R, Kazemi E, Mahmoodian L, Mirzaei A, Soleymanifard A. Study on effects of different plant density on seed yield, oil and protein content of four canola cultivars in western Iran. International Journal of Agriculture and Crop Sciences. 2012; 4(2):70-78.

12. Pachauri RK, Trivedi SK, Yogendra K. Effect of sulphur levels on growth, yield and quality of Indian mustard genotypes and their economics. Journal of Soils and Crops. 2012; 22(2):258-263.

13. Panda BB, Bandyopadhyay SK, Shivay YS. Effect of irrigation level, sowing dates and varieties on growth, yield attributes, yield, consumptive water use and water use efficiency of Indian mustard (Brassica juncea L.). Indian Journal of Agricultural sciences. 2004; 74:331342.

14. Patel A, Singh AK, Singh SV, Sharma A, Raghuvanshi N, Singh AK. Effect of different sowing dates on growth, yield and quality of various Indian mustard (Brassica juncea L.) varieties. International Journal of Current Microbiology and Applied Sciences Special. 2017; 4:7177.

15. Piri I, Nik MM, Tavassoli A, Rastegaripour F. Effect of irrigation intervals and sulphur fertilization on growth analyses and yield of Brassica juncea. African Journal of Microbiology Research. 2011; 5:3640-3646.

16. Rashid MM, Moniruzzaman M, Masud MM, Biswas PK, Hossain MA. Growth parameters of different mustard (Brassica campestris L) varieties as affected by different levels of fertilizers. Bulletin of the Institute of Tropical Agriculture, Kyushu University. 2010; 33(1):73-81.

17. Saud RK, Singh DP. NPK content and uptake in Indian mustard (Brassica juncea) varieties as influenced by limited irrigation and nitrogen levels. Advance Research Journal of Crop Improvement. 2011; 2(1):131-134.
18. Shanker K, Parihar SKS, Kuldeep KKD, Kumar A. Relative salt tolerance of Indian mustard (Brassica juncea) genotypes in relation to germination, growth and seed yield. Journal of Oilseed Brassica. 2011; (2):76-82.

19. Sharma P. Effect of varieties and fertility levels on yield and nutrient uptake of mustard in western region of Madhya Pradesh. TECHNOFAME- A Journal of Multidisciplinary Advance Research. 2013; 2(2):67-69.

20. Singh AK, Singh H, Rai OP, Singh G, Prakash V, Singh NPS, Singh R. Effect of sowing dates and varieties for higher productivity of Indian mustard (Brassica juncea L.). Journal of Applied and Natural Science. 2017; 9(2):883-887.

21. Singh RK, Singh AK, Kumar R. Effect of fertility level on nutrient uptake, yield and quality of Indian mustard Brassica juncea (L.) czern and coss varieties under late sown condition. Environment \& Ecology. 2010; 28(3A):1764-1767.

22. Thakuria K, Thakuria C. Seed rate and row spacing effect on yellow sarson (Brassica rapa var. trilocularis) under rainfed conditions. Journal of Oilseeds Research. 2014; 31(1):77-78. 